Vol.3 No.2 Hal. 57-61

September 2020
BEST JOURNAL

(Biology Education,Science \& Technology)

Fakultas Keguruan dan Ilmu Pendidikan
ISSN (Print) : $2614-8064$

ISSN (Online): $2654-4652$

\title{
Dampak Penggunaan Gadget Terhadap Perkembangan Anak
}

\author{
Rizky Nafaida $^{(1)}$, Nurmasyitah $^{(2)}$, Nursamsu $^{(3)}$ \\ Pendidikan Biologi dan Pendidikan Fisika Fakultas Keguruan dan Ilmu Pendidikan \\ Universitas Samudra ${ }^{(1)(2)(3)}$ \\ $\underline{\text { ekariana@unsam.ac.id }}^{(1)}$, nurmasyitah@unsam.ac.id ${ }^{(2)}$, $\underline{\text { samsu_bio@unsam.ac.id }}^{(3)}$
}

\begin{abstract}
ABSTRAK
Penelitian ini bertujuan untuk mengetahui penguatan gadget terhadap perkembangan karakter anak. metode penelitian adalah yang digunakan dalam penelitian berupa metode deskriptif. Pengumpulan data dilkasanakan mengunakan observasi dan angket sedangkan pada analisa data dilakukan dengan reduksi data, penyajian data, penyimpulan dan verifikasi data. Hasil penelitian dinyakan dengan nilai 76,80\% dinyatakan baik karakter religius, karakter peduli sosial dengan nilai 73,87\% dinyatakan baik, karakter disiplin dinyatakan baik dengan nilai $67,73 \%$, sedangkan karakter tanggung jawab dengan nilai $76,53 \%$ dinyatakan baik. Maka dapat disimpulkan bahwa penggunaan gadget terdapat dampak positif dan negatif bagi anak.
\end{abstract}

Kata Kunci : Gadget, Dampak, Karakter

\begin{abstract}
This study aims to determine the strengthening of gadgets on the character development of children. Research methods are those used in research in the form of descriptive methods. Data collection was carried out using observations and questionnaires while in data analysis carried out by data reduction, data presentation, inference and verification of data. The results of the study presented with a value of $76.80 \%$ expressed good religious character, social care character with a value of $73.87 \%$ expressed good, disciplined character stated well with a value of $67.73 \%$, while the character of responsibility with a value of $76.53 \%$ expressed good. Then it can be concluded that the use of gadgets have positive and negative impacts on children.
\end{abstract}

Keywords : Gadgets, Impact, Character 


\section{PENDAHULUAN}

\section{Latar Belakang}

Pada zaman abad 21 ini terjadi suatu perkembangan dan kemajuan di bidang ilmu pengetahuan dan teknologi yang begitu pesatnya. (Ameliola, S., Nugraha, 2013). Dimana Perkembangan teknologi dan informasi telah menguasai dunia yang mempunyai kemajuan secara cepat, dapat kita contohkan kemajuannya seperti bidang informasi dan teknologi, dan bangsa Indonesia merupakan salah satu bangsa yang ikut terlibat dalam kemajuan media informasi dan teknologi. Pada tahun 2020 ini Indonesia sudah memberlakukan pembelajaran secara terknologi menggunakan gadget sebagai medianya. Menurut pendapat Fathoni (2017) mengungkapkan bahwa Gadget merupakan teknologi yang sangat populer sekarang ini, bukan hanya bagi orang dewasa namun masih anak-anak menggunakan gadget. Dimana banyak produk-produk gadget yang menjadikan anak- anak sebagai target pasar mereka. Bahkan termasuk konsumen yang aktif pengguna gadget. Gadget juga diartikan sebuah istilah dalam bahasa Inggris yang mengartikan sebuah alat elektronik kecil dengan berbagai macam fungsi khusus (Chusna, 2017). Gagdet merupakan alat elektronik yang digunakan sebagai media informasi, media belajar dan sebagai hiburan (Warisyah, 2015). Penggunaan teknologi akan berdampak kepada anak baik dari segi positif maupun negatif tergantung bagaimana orang tua mendidiknya. Begitu pula dengan masa anak-anak menurut Hurlock (2016) merupakan masa dimana anak-anak akan dimulai dari bayi, yakni usia 2 tahun sampai anak matang secara seksual. Selama periode usia 11 tahun bagi perempuan dan 12 tahun bagi laki-laki terjadi perubahan yang signifikan, baik secara fisik maupun psikologis. Pada usia anak 6-12 tahun adalah usia anak pada tingkat sekolah dasar. Perkembangan pada anak juga cepat dari perkembangan fisik dan psikologinya. Oleh sebab itulah sebagai orang tua berperan untuk memantau anak dalam perkembangan teknologi. Memberikan gadget pada anak tanpa adanya pengawasan orang dewasa atau orang yang lebih tua memang akan cenderung menimbulkan beberapa dampak negative, seperti halnya pendapat Wulan Patria Saroinsong (2016) yang mengungkapkan Penggunaan gadget akan berdampak merugikan setiap keterampilan interpersonal dan anak lebih menghandalkan gadget dari pada kemampuan pada dirinya. Dampak negative juga terdapat pada radiasi didalam gadget dapat merusak pada sistem jaringan syaraf dan otak anak, dimana si anak menurunkan daya aktif anak dalam melakukan suatu interaksi kepada orang lain karena anak lebih suka menyendiri dengan gadgetnya. Gadget juga bukan hanya berdampak negatif akan tetapi berdampak positif misalnya tidak hanya memang memiliki dampak positif bagi pola pikir anak yaitu membantu anak dalam mengatur kecepatan bermainnya, mengolah strategi dalam permainan, dan membantu meningkatkan kemampuan otak kanan. Berdasarkan pendapat diatas observasi awal tim penelitian ke lokasi gampong sungai pauh firdaus untuk mengindentifikasi anak sekolah tingkat SD.

\section{Perumusan Masalah}

Permasalahan yang kami dapatkan dari observasi awal sebagai tim penelitian dosen pemula untuk proses pembelajaran pada masa pandemi covid-19. Ketika kami bersosialisasi ke rumah sebagai sampel penelitian banyak ibu - ibu dari anak yang akan kami jadikan sampel penelitian mengeluh. Bahwasanya anak - anak lebih banyak menggunakan gadget untuk belajar dirumah, karena pada pandemi covid-19 diwajibkan belajar daring. Padahal kita tahu bahwa pembelajaran menggunakan gadget ada dampak positif dan negatif. Makanya sebagai orang tua wajib mendampingkan anak dalam pembelajaran berlangsung. Permasalahan ini berkaitan dengan penelitian Syifa Ameliola (2010) menyatakan media informasi dan teknologi ini tidak berdampak positif dan negatifnya, tergantung cara penggunaan individu. Sedangkan pendapat Yulia Trinika (2015), Ada pengaruh antara penggunaan gadget terhadap perkembangan psikososial anak. Beranjak dari pendapat tersebut maka penelitian 
akan melakukan mengenai penggunaan gadget terhadap perkembangan karakter anak. Penelitian menggarahkan empat karakter siswa dalam penggunaan gadget yaitu karakter religius, peduli sosial, disiplin dan tanggung jawab.

\section{Tujuan Penelitian}

Penelitian ini bertujuan dari penggunaan gadget terhadap perkembangan karakter anak, konsep ini akan menggukur karakter anak. Karakter ini akan di ukur untuk kebiasaan anak menggunakan gadget apakah dapat mempengaruhi karakternya yaitu karakter religius berhubungan dengan ketaatan si anak, mana bahwa di Aceh merupakan propinsi berbasis syariat makanya disekolah diwajibkan kepada anak menanam nilai karakter religius. Permasalahan pada saat ini belajar melalui daring menggunakan gadget, maka si anak wajib melaksanakan ibadah dirumah.

\section{Manfaat Penelitian}

Manfaat yang akan didapat dari penelitian ini adalah Kegiatan ibadah ini dikirimkan kepada guru sebagai penilaian karakternya. Karakter peduli sosial merupakan karakter anak peka terhadap lingkungan sekitarnya, khususya di keluarga. Karakter disiplin membetuk kesiplin pada dirinya mengenai agar mengerjakan tugas sesuai dengan jadwal yang telah ditentukan sedangkan karakter tanggung jawab membiasakan anak agar mengerjakan tugas dapat menyelesaikan tepat waktu. Sesuai dengan pendapat Arif (2017: 138) menyebutkan bahwa istilah karakter secara harfiah berasal dari bahasa Latin "Charakter", yang antara lain berarti: watak, tabiat, sifat-sifat kejiwaan, budi pekerti, kepribadian atau akhlak

\section{METODE PENELITIAN}

Metode yang digunakan dalam penelitian berupa metode deskriptif, yaitu memberikan gambaran yang jelas berkenaan dengan peran orang tua dalam penggunaan gadget terhadap perkembangan karakter anak.

\section{Populasi dan Sampel Penelitian}

Populasi penelitian ini seluruh anak yang berjenjang pendidikan SD yang terhitung setiap keluarga yang mempunyai anak sudah sekolah tingkat SD berjumlah 50 orang. Sedangkan sampel dalam penelitian diambil sebahagian dari polulasi berjumlah 15 orang anak bersekolah tingkat SD.

\section{Teknik Pengumpulan Data}

Proses pengumpulan data akan dilakukan oleh tim penelitian adalah observasi, wawancara, dokumentasi sedangkan instrumen penelitian adalah berupa angket karakter yang di berikan kepada anak di Gampong Sungai Pauh Firdaus.

\section{Teknik Analisa Data}

Untuk mendapatkan hasil dari kegiatan pengumpulan data diatas maka tim akan mentabulasi data sebagai berikut: (1) reduksi data; (2) penyajian data; (3) penyimpulan; (4) verifikasi data.

\section{HASIL DAN PEMBAHASAN Hasil Penelitian}

Pelaksanaan observasi dilaksanakan ke lokasi penelitian yaitu menjumpai Bapak Geuchik untuk mendapatkan izin penelitian dan menetukan jadwal kegiatan penelitian. Observasi kami disambut dengan baik. Proses yang kami dilaksanakan tidak mengumpulkan orang, namun menjumpai perorang langsung kerumah penduduk Gampong Sungai Pauh Firdaus. Hasil yang didapatkan dari penyebaran angket berdampak positif dan negatif bagi anak yang menggunakan gadget dalam perkembangan karakternya. Apalagi Pada masa pandemi covid19 dunia pendidikan terjadi lumpuh tidak adanya kegiatan pembelajaran disekolah, namun 
pembelajaran dilaksanakan dengan jarak jauh. Hal ini menyebabkan anak - anak wajib menggunakan gadget sebagai alat media pembelajaran daring atau belajar jarak jauh. Maka perkembangan karakter si anak di awasi oleh orang tuanya. Adapun dampak karakter positif dalam penggunaan gadget sebagai alat media belajar bagi anak, dapat dijelaskan pada gambar dibawah ini.

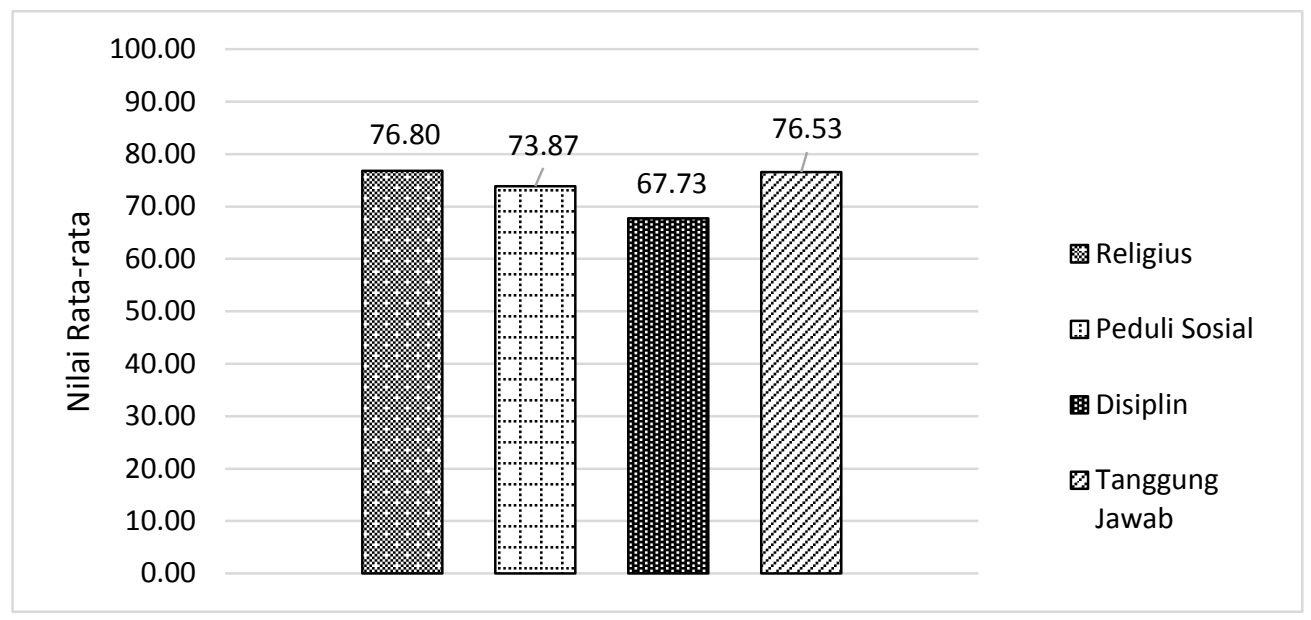

Gambar 1. Persentase rata - rata nilai dampak positif penggunaan gadget

Penjelasan gambar diatas yang terbagi atas empat karakter yang berdampak posif bagi anak adalah karakter religius dengan nilai 76,80\% dinyatakan baik. Penggunaan gadget pada masa pandemi covid-19 anak dapat terkontrol ibadahnya, karena tugas disekolah anak wajib merekam dalam satu hari wajib beribadah yang menjadi penilaian si anak. Karakter peduli sosial dengan adanya pembelajaran daring anak saling informasi pengetahuan sesama temannya untuk berdiskusi materi apa saja yang dipelajari menjadi tugas. Hasil yang didapatkan 73,87\% dinyatakan baik. Sedangkan karakter disiplin dinyatakan baik dengan nilai $67,73 \%$, anak terbiasa disiplin untuk menyesaiankan tugas dari sekolah sesuai dengan jadwal yang ditentukan. Selanjutnya karakter tanggung jawab dengan nilai $76,53 \%$ dinyatakan baik, hal ini menunjukan pertanggungjawaban si anak untuk mengerjakan tugasnya tepat pada waktunya untuk penyelesaiannya. Dampak negatif penggunaan gadget juga terjadi pada anak - anak semenjak sering menggunakan media gadget untuk kegiatan belajar jarak jauh seperti anak kurang beristirahat, anak lebih malas, membahayakan kesehatan mata akibat radiasinya, anak lebih suka menyendiri dengan gadgetnya.

\section{PEMBAHASAN}

Tekhnologi pada abad 21 memberikan dampak positif dan negatif bagi anaknya. Tergantung bagaimana orang tua menyikapi perkembangan karakter anaknya. Hal ini sedana dengan pendapat Wulan Patria Saroinsong (2016) menyatakan bahwa penggunaan gadget berdampak merugikan pada keterampilan interpersonal anak jika terlalu sering digunakan. Ketergantungan siswa pada Smartphone secara langsung membuat mereka malas belajar. Pada dasarnya dalam belajar sangat diperlukan adanya motivasi (Habibi, dkk. 2018). Dengan demikian sebagai orang tua menanamkan nilai karakter bagi anak, agar anak tidan menyimpang karakternya. Sebagaiman pendapat menurut Muslich (2011:1) menyatakan bahwa pendidikan karakter merupakan suatu pondasi bangsa yang sangat penting dan perlu ditanamkan sejak dini kepada anak-anak. Demikian pula Kurniawan (2014: 22) berpendapat bahwa pentingnya pendidikan karakter sejak usia dini kanak-kanak atau yang biasa disebut 
para ahli psikologi sebagai usia emas (golden age), menurutnya dalam usia ini terbukti sangat menentukan kemampuan anak dalam mengembangkan potensinya.

\section{KESIMPULAN}

Berkaitan dengan uraian di atas maka hasil penelitian dapat disimpulkan bahwa.

1. Dampak positif penggunaan gadget dapat membentuk karakter religius, peduli sosial, disiplin dan tanggung jawab dari empat karakter dikategorikan baik.

2. Dampak negatif tercemin pada si anak dalam penggunaan gadget bagi aktivitas sehari hari adalah anak kurang beristirahat, anak lebih malas, membahayakan kesehatan mata akibat radiasinya, anak lebih suka menyendiri dengan gadgetnya.

3. Perlu adanya pengawasan orang tua, karena perkembangan karakter terbentuk dari lingkungan keluarga.

\section{DAFTAR PUSTAKA}

Ameliola Conference On Indonesian Studies Ethnicity and Globalization "Perkembangan Media Informasi dan Teknologi Terhadap Anak Dalam Era Globalisasi", Fakultas Pertanian. UNIVERSITAS BRAWIJAYA MALANG.Syifa, Hanggara Dwiyudha Nugraha, 2010. Penelitian Prosiding The 5 International.

Ameliola, S., Nugraha, D. . (2013). Perkembangan Media Informasi Dan Teknologi Terhadap Anak Dalam Era Globalisasi. Universitas Brawijaya. Diakses pada tanggal 20 Juni 2020 dari Http://Icssis.Files.Wordpress.Com/2 013/09/2013-02- 29.Pdf.

Arif, Rifda Mardian. 2017. Implementasi Pendidikan Karakter dalam Pembelajaran Sains. Stilistika: Jurnal Bahasa, Sastra, dan Pembelajarannya, Vol. 2 No 1, Tahun 2017, Hlm. 135- 150.

Chusna, P. A. (2017). Pengaruh Media Gadget Pada Perkembangan Karakter Anak. Dinamika Penelitian: Media Komunikasi Sosial Keagamaan, 17(2), 315-330. Diakses pada tanggal 25 Juni 2020 dari Https://Doi.Org/10.21274/Dinamika/2017.17.2.315$\underline{330 .}$.

Fathoni, A. R. (2017). Pengaruh Gadget Terhadap Perkembangan Anak Usia Dini. Diakses $\begin{array}{lllll}\text { pada } & \text { tanggal } & 27 & \text { Juni } & 2020\end{array}$ Http://Www.Artikelcakep.Top/2017/10/PengaruhgadgetTerhadapPerkembangananak - Artikelcakep.Html.

Hurlock, E. B. (2016). Psikologi Perkembangan (Suatu Pendekatan Sepanjang Rentang Kehidupan) (5th Ed). Erlangga.

Habibi, M., Chandra, C., Mahyuddin, R., \& Hendri, S. (2018). Validity of Teaching Materials for Writing Poetry Based on Creative Techniques in Elementary Schools. Mimbar Sekolah Dasar, 5(3), 145-154. ttps://doi.org/10.17509/mimbar- sd. v5i3.14501.

Kurniawan, S. (2014). Pendidikan Karakter: Konsepsi dan Implementasinya Secara Terpadu di Lingkungan Keluarga, Sekolah, Perguruan Tinggi, dan Masyarakat. Yogyakarta: Ar-Ruzz Media.

Muslich, M. (2011). Pendidikan Karakter Menjawab Tantangan Krisis Multidimensional. Jakarta: Bumi Aksara.

Trinika Yulia, (2015). Skripsi "Pengaruh Penggunaan Gadget Terhadap Perkembangan Psikososial Anak", Fakultas Kedokteran. UNIVERSITAS TANJUNGPURA.

\begin{tabular}{|l|l|l|l|}
\hline Accepted Date & Revised Date & Decided Date & Accepted to Publish \\
\hline 01 Agustus 2020 & 04 Agustus 2020 & 10 Agustus 2020 & Ya \\
\hline
\end{tabular}

